\title{
Linking forest diversity and tree health: preliminary insights from a large-scale survey in Italy
}

\author{
Filippo Bussotti ${ }^{1 *}$ D, Matteo Feducci ${ }^{1}$, Giovanni lacopetti ${ }^{1}$, Filomena Maggino ${ }^{2}$, Martina Pollastrini ${ }^{1}$ \\ and Federico Selvi ${ }^{1}$
}

\begin{abstract}
Forest health is currently assessed in Europe (ICP Forests monitoring program). Crown defoliation and dieback, tree mortality, and pathogenic damage are the main aspects considered in tree health assessment. The worsening of environmental conditions (i.e., increase of temperature and drought events) may cause large-spatial scale tree mortality and forest decline. However, the role of stand features, including tree species assemblage and diversity as factors that modify environmental impacts, is poorly considered. The present contribution reanalyses the historical dataset of crown conditions in Italian forests from 1997 to 2014 to identify ecological and structural factors that influence tree crown defoliation, highlighting in a special manner the role of tree diversity. The effects of tree diversity were explored using the entire data set through multivariate cluster analyses and on individual trees, analysing the influence of the neighbouring tree diversity and identity at the local (neighbour) level. Preliminary results suggest that each tree species shows a specific behaviour in relation to crown defoliation, and the distribution of crown defoliation across Italian forests reflects the distribution of the main forest types and their ecological equilibrium with the environment. The potentiality and the problems connected to the possible extension of this analysis at a more general level (European and North American) were discussed.
\end{abstract}

Keywords: Cluster analysis, Crown defoliation, Forest structure, ICP Forests, Neighbouring trees, Tree diversity, Tree identity

\section{Highlights}

- The role of tree diversity on crown defoliation was assessed in a large-scale monitoring network.

- No positive effect of tree diversity was found at a national scale.

- Each tree species showed its own 'signature' for crown defoliation.

- The level of crown defoliation at each plot depends on which species are present and their biotic and abiotic interactions.

- Crown defoliation of individual trees is more affected by identity than diversity of their neighbouring trees.

\footnotetext{
* Correspondence: filippo.bussotti@unifi.it

'Department of Agri-Food Production and Environmental Sciences (DISPAA), University of Firenze, Piazzale delle Cascine, 18 -, 50144 Florence, Italy Full list of author information is available at the end of the article
}

\section{Background}

Health conditions of European forests are assessed since some decades in an extensive network (Level I) within the ICP Forests program (International Cooperative Programme on Assessment and Monitoring of Air Pollution Effects on Forests). This program was launched as part of CLRTAP (Convention on Long-Range Transboundary Air Pollution) implemented by EMEP (European Monitoring and Evaluation Programme) and directed by UNECE (United Nations Economic Commission for Europe) and was primarily devoted at assessing the effects of atmospheric deposition and air pollution on forests. Although focused on air pollution, new environmental challenges such as climate change and pathogenic invasions are included in recent years within the goals of the program (ICP Forests 2016). In this new perspective, the suitability of the tree health indicators 
currently adopted for terrestrial assessment (mainly crown defoliation, Ferretti and Fisher 2013) may be questioned (Bussotti and Pollastrini 2017a, b).

Correlations between tree crown defoliation and air pollution were rather weak and often non-significant at the European scale (Klap et al. 2000; Johnson and Jacob 2009), but these correlations may become stronger in analyses carried out at local and national level. A significant role of atmospheric deposition and ozone as factors involved in worsening crown conditions was proposed by Augustatis et al. (2007) in Lithuania, whereas ozone levels (but not fluxes) were connected to crown defoliation and discoloration in Southern France, Northern Italy (Sicard et al. 2016) and Romania (De Marco et al. 2017). Climatic fluctuation and extremes, however, have been recognized as the main powerful factors that drive spatial distribution and temporal changes of forest tree health, vitality, and productivity (Carnicer et al. 2011; Ferretti et al. 2014; de la Cruz et al. 2014; Bussotti et al. 2015; Popa et al. 2017).

Recently, increasing importance is attributed to the structure and composition of forest stands, especially to tree diversity, as factors influencing tree health and productivity. Experimental and observational pieces of evidence show that tree diversity has a positive effect on productivity (Baeten et al. 2013; Verheyen et al. 2016) and plays a stabilising role on annual growth rates of trees (Jucker et al. 2014). Upscaling experimental and observational results at a large-spatial scale presents difficulties because of the complexity and the variability of the biological and ecological interactions (Leuzinger et al. 2011). Forest inventories, however, can play a relevant role in the assessment of forest biodiversity (Corona et al. 2011) and its beneficial effects on tree growth and stand productivity (Ruiz-Benito et al. 2014; Watson et al. 2015; Liang et al. 2016). Interestingly, Ratcliffe et al. (2015) proved that tree diversity plays a more relevant role in enhancing growth in Mediterranean regions (water limited) than in continental forests.

The possible effects of tree diversity on defoliation are poorly investigated, until now. Eichhorn et al. (2005) identified tree diversity as a relevant factor that positively influences the crown conditions (i.e., reduced crown defoliation) at the stand level in oak-beech mixed forests in Germany. Species-specific effects of tree diversity on crown defoliation were also observed by Pollastrini et al. (2016) in observational plots in Tuscany (Italy).

It is generally accepted that tree diversity reduces the intensity of attacks by herbivorous insects (Jactel and Brockerhoff 2007; Guyot et al. 2015) through different mechanisms. According to the resource concentration hypothesis (Root 1973), the probability of a host plant to be located by insects decreases in mixed forests. Moreover, non-host plants could disrupt chemical or physical cues used by herbivores to locate a suitable host (Huber and Borden 2001; Castagneyrol et al. 2013). In addition, the natural enemy hypothesis (Root 1973; Russell 1989) suggests that more diverse plant assemblages provide natural enemies with more complementary resources and habitats, thereby promoting top-down regulation of herbivores (Guyot et al. 2015).

Pathogenic root fungi reduce their virulence in mixed forest stands or when the proportion of host trees is lower (Lindén and Vollbrecht 2002; Thor et al. 2005; Nguyen et al. 2016) because of the reduced plant-byplant root connections in mixed stands. By contrast, airborne pathogens of mature trees may show different patterns. Mixed forests may provide more suitable microclimates for fungi (e.g., higher humidity) than monocultures (Lodge and Cantrell 1995; Jules et al. 2014). Furthermore, the predominance of generalist pathogen species that can spill over from one host tree to another could increase the inoculum and, consequently, the incidence of diseases in mixed stands (Maloney et al. 2005; Parker et al. 2015).

Several questions should be addressed for a proper analysis of forest health conditions in relation to tree diversity. The first need is to refine the choice of parameters to describe the actual physiological and health conditions of trees. The threshold of 25\% (Michel and Seidling 2016) for defoliation was settled arbitrarily and does not have a true physiological meaning (Lorenz et al. 2007). Drobyshev et al. (2007) and Nakajima et al. (2011) suggested negative correlations between crown defoliation and tree growth, but this effect is not confirmed at wider scale. Searching for new defoliation thresholds, and for a combination of symptoms (Eichhorn et al. 2016) within synthetic indices (Pollastrini et al. 2015), as well as their subsequent validation as predictor of growth reduction and/or mortality, is an inescapable task. Secondly, the analysis of the complexity of interactions between tree species composition, forest structure, and ecological characteristics of the site claims for the adoption of the most advanced statistical tools (Green et al. 2005). Such analysis must take in account the adaptation and/or vulnerability of forest tree assemblages and their possible divergent responses to stress factors, such as extreme climate events (Carnicer et al. 2011). Tree functional traits should also be included as predictive factors (Bussotti 2008). Finally, there is the problem of capturing impacts unevenly distributed (e.g., at the edges of populations), and that may be not represented in a systematic monitoring network.

This study represents a first attempt to explore the role of tree diversity as a factor contributing to tree health through the ICP Forests (Level I) data at the national (Italian) level, highlighting the problems connected to this 
analysis and the needs for more effective tools of elaborations.

\section{Methods}

\section{The level I network in Italy}

In Italy, the Level I - ICP Forests monitoring network consisted of 245 plots (year 2014), with 4967 trees subdivided into 1310 conifers and 3656 broad-leaved trees. Ten to thirty trees per plot were assessed. The most frequent tree species are listed in Table 1. The plots are circular with a fixed $13 \mathrm{~m}$ radius, and the crown conditions of all trees with diameter at breast height $(\mathrm{DBH})>10 \mathrm{~cm}$ are assessed yearly. DBH is measured every 5 years. The field crews of the National Forest Service (formerly Corpo Forestale dello Stato, from 2017 Carabinieri Forestali) are trained before each field survey (Ferretti et al. 1999; Bussotti et al. 2009) using a national field manual (Bussotti et al. 2016; Gasparini et al. 2016). In this contribution, the crown condition was evaluated for the historical series from 1997 to 2014.

The main indicator of forest health in the ICP Forests program is the 'crown defoliation' (Eichhorn et al. 2016). It integrates intrinsic tree genetic variability, site effects, and external factors such as abiotic and biotic stresses. Crown defoliation expresses the percentage of lacking leaves with respect to an ideal healthy tree identified through photo guides (Müller and Stierlin 1990; Ferretti 1994) or local reference tree and it is measured by a proportional scale with $5 \%$ steps ranging from $0 \%$ (not defoliated) to $100 \%$ (dead tree). Alongside crown defoliation, damage symptoms (and, when evident, damaging agents) are currently assessed on leaves, branches, and trunk. The most widely used method to report the results is the percentage of trees for a sample population with crown defoliation higher than 25\% (Michel and Seidling 2016), both at plot and national/European levels.

In the data set used for this study, the following variables are considered for each plot:

Table 1 Total number ( $\mathrm{Nr}$ ) and percentage (\%) of tree with crown defoliation higher, respectively, than 25\% and 60\% (trees highly defoliated) for the most common tree species in Italy (survey 2014)

\begin{tabular}{llll}
\hline Tree species & Total Nr & $\begin{array}{l}\text { Crown defoliation: } \\
\text { \% of trees } \\
\text { with Def. > 25\% }\end{array}$ & $\begin{array}{l}\text { Crown defoliation: } \\
\text { \% of trees with } \\
\text { Def. > 60\% }\end{array}$ \\
\hline Fagus sylvatica & 1210 & 21.04 & 2.45 \\
Quercus pubescens & 819 & 35.52 & 2.91 \\
Quercus cerris & 697 & 24.39 & 4.66 \\
Castanea sativa & 550 & 61.78 & 15.06 \\
Picea abies & 501 & 21.57 & 4.01 \\
Larix decidua & 415 & 19.54 & 3.55 \\
Pinus sylvestris & 241 & 28.45 & 2.64 \\
\hline
\end{tabular}

- Physical variables: geographical position (longitude and latitude) and altitude.

- Ecological variables: climatic parameters (rainfall and temperature data collected from www.worldclim.org); soil parameters (soil depth, $\mathrm{pH}$, $\mathrm{C} / \mathrm{N}$ ratio, Cationic Exchange Capacity - CEC, exchangeable elements collected within BioSoil project, www.forestry.gov.uk/fr/biosoil, and provided by the Italian National Forest Service).

- Vegetation variables: basal area per hectare, tree species composition and tree diversity. Tree diversity is calculated as taxonomic diversity (TD, Shannon and Simpson indices), functional diversity (FD) calculated as CWM (i.e., community weighted mean, Lavorel et al. 2008), and Rao's quadratic entropy (FD, Functional Divergence, see Rao 1982a, b). The functional traits considered to calculate FD in this study are specific leaf area (SLA), wood density (WD), seed mass (SM), leaf nitrogen content $(\mathrm{N})$, and tree maximum height $(\mathrm{H})$. The relative values of the functional traits for each species included in this study were derived from current public databases and literature (see Pollastrini et al. 2016; Liebergesell et al. 2016, with references and annexes therein).

Considering that the plots of the survey are distributed on a systematic network, some difficulties in this study are related to a non-balanced distribution at the national level of tree species, diversity levels, and ecological factors.

\section{Statistical analyses}

The dataset includes all the data collected in Italy from 1997 to 2014. The number of plots and trees, as well the protocols for the field surveys, varied during the years. The variable considered (crown defoliation), however was consistent during the whole assessment period. Dataset implementation and exploratory analyses were performed in $R$ ( $R$ Core Team 2016). The general strategy for data processing consisted, as a first step, of reducing the extreme complexity and variability of the dataset by identifying more homogenous groups of plots. To achieve the expected result, two clustering techniques were used. A preliminary hierarchical clustering, considering all the explaining variables previously listed (physical, ecological, and vegetational), was carried out to assess the suitability of the dataset for clustering and explore the robustness of different metric and aggregation methods. This analysis was applied to define the number of clusters, and was performed using a complete aggregation method over the Euclidean distances. The variables connected to 'species' (a dummy variable, descriptive and without numerical significance) and 'crown 
defoliation' (which are the variables we aim to predict) were excluded from this analysis. For the final clustering, the data were standardised (average zero and standard deviation one), and the k-medoids method was applied and implemented in the 'pam()' function of the 'cluster' package in $\mathrm{R}$ (Maechler et al. 2016). This method can work with missing data, and it is more robust to noise and outliers. Therefore, it is more suitable for large and potentially problematic databases. The k-medoids algorithm was used with the same exclusion principles of the preliminary clustering and the same Euclidean metric, and was applied to define the composition of the clusters. Graphical plots of regression analysis between crown defoliation severity and tree diversity were obtained with ggplot2 (Wickham 2009) package, fitting a generalised additive model. For surrounding trees analysis, Shannon and Simpson diversity indices were calculated in the neighbourhood of target trees (Picea abies [L.] H. Karst as model tree species was selected). All trees closer than five meters from the target tree were included in its neighbourhood. The species and DBH of neighbouring trees were recorded.

\section{Results}

\section{Descriptive statistics}

The geographic national distribution of species and functional groups reflects the differences between climatic regions in Italy and their respective dominant
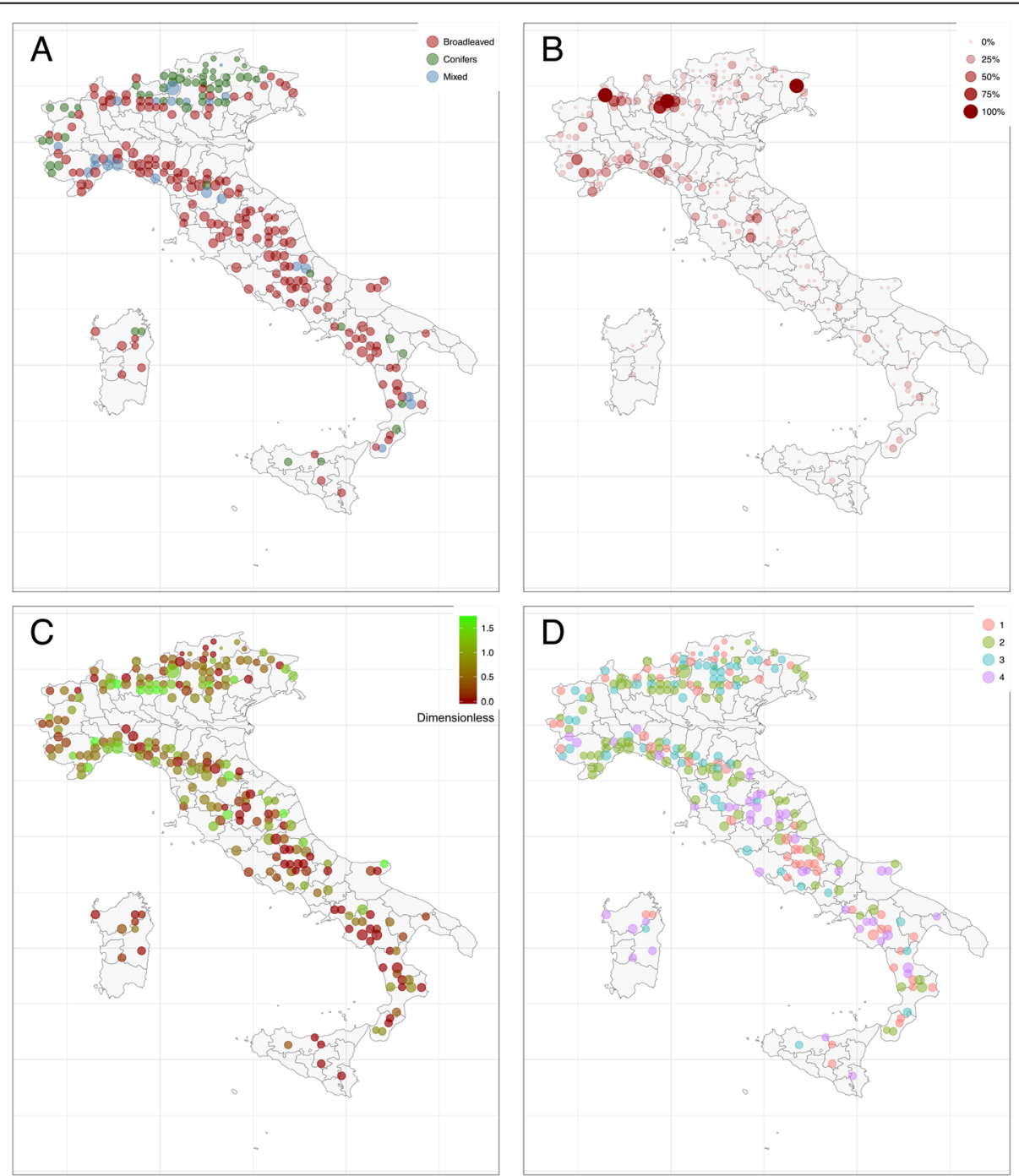

Fig. 1 a: Distribution of conifer, broadleaves and mixed forests of the Italian ICP Forests network (Level I). b: Distribution of the severity of defoliation per plot. Each point expresses the percentage of trees with defoliation $>60 \%$ at a given plot. c: Tree diversity (Shannon Index) for each plot, dimensionless. d: Distribution of the plots aggregated according to the results of the cluster analysis, taking in account physical, ecological and vegetational characteristics. The number in legend indicates the cluster (see Fig. 3) 
forest types (Fig. 1a). Conifers (namely P. abies) are dominant at higher elevations (up to $1800 \mathrm{~m}$ a.s.l.) in the Alpine range (North Italy). Among broad-leaves, Fagus sylvatica $\mathrm{L}$. is distributed at the intermediate elevation (800-1200 m a.s.l.) in the Alps, and it is the most common species at the high elevation (1000-1500 m a.s.l.) in the entire Apennine chain in Central and Southern Italy. At lower and intermediate elevations (up to 700$800 \mathrm{~m}$ a.s.l.), oak forests are dominant. Oak species include the deciduous species Quercus cerris L. and Quercus pubescens Willd. and the evergreen Quercus ilex L. Monospecific or few species-mixed forests are prevailing at high and low elevations, whereas the more diverse forests are distributed in the hills and in the intermediate mountain belt.

Crown defoliation rates are higher in broadleaved than in coniferous tree species (in the period 1997-2014, the mean percentage of trees with defoliation $>25 \%$ was 39.7 for broadleaves and 24.1 for conifers). The distribution of defoliation severity at the plot level (highly defoliated trees with defoliation $>60 \%$ ) is shown in Fig. $1 \mathrm{~b}$ and suggests the presence of a 'hot spot' in the northwestern regions. The tree diversity (Shannon Index) for each plot is shown in Fig. 1c.

The temporal pattern of crown defoliation shows two distinct behaviours for conifers and broadleaves (Fig. 2):
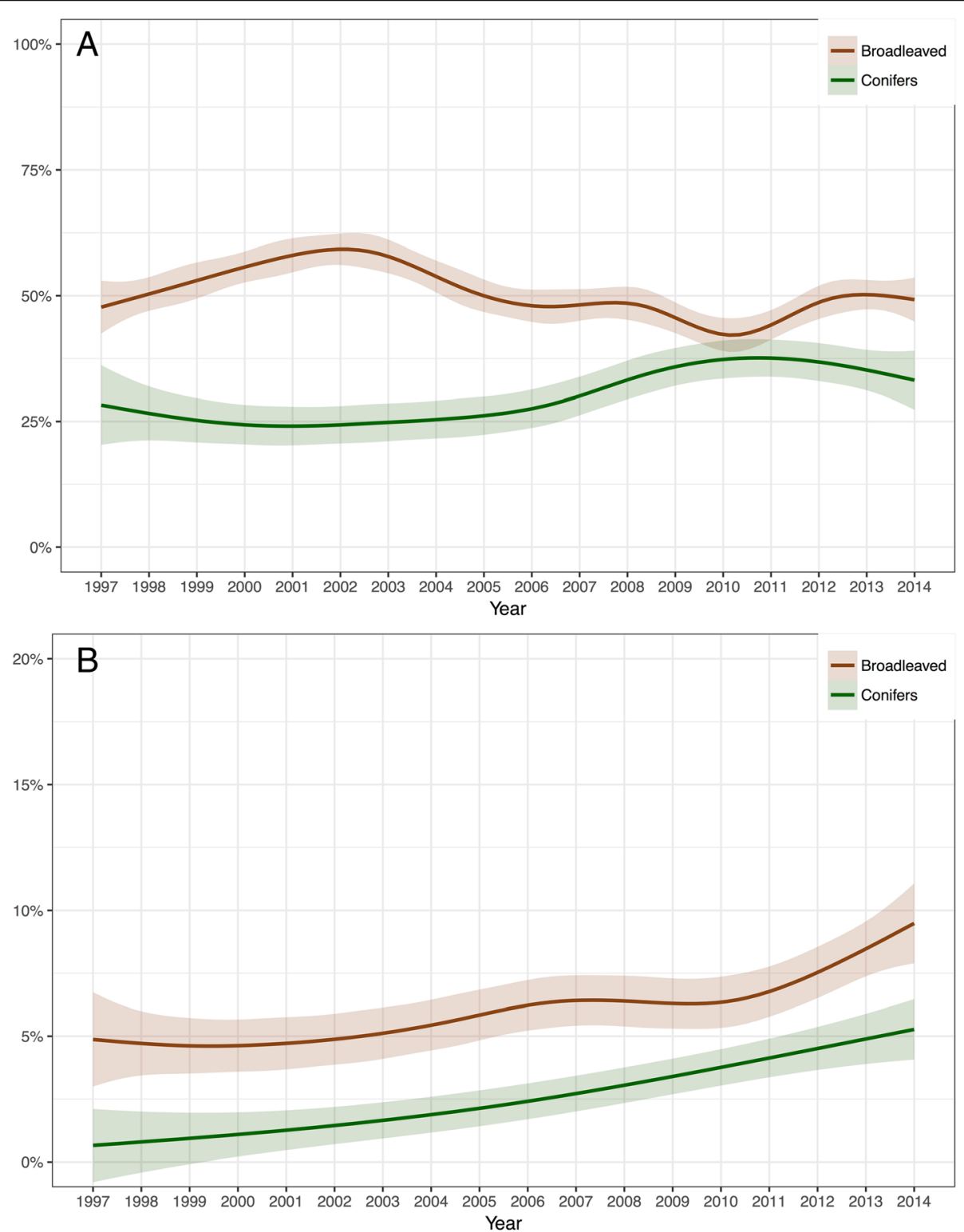

Fig. 2 Pattern of defoliation over time (expressed as percentage of defoliated trees during the period 1997-2014). a: Percentage of trees with defoliation $>25 \%$. b: Percentage of trees with defoliation $>60 \%$ 
between the years 1997 and 2000, the crown defoliation increased in broad-leaves and decreased in conifers. The opposite behaviour can be observed between 2001 and 2010. In both functional groups, the percent of highly defoliated trees (defoliation $>60 \%$ ) increased over time (Fig. 2b).

\section{Cluster analysis}

The cluster analysis allowed to individuate four clusters of plots in relation to the set of geographical, ecological, and vegetational parameters described in Materials and Methods. Their geographic distribution is shown in Fig. $1 d$. The main characteristics of each cluster are shown in Fig. 3 alongside the severity of defoliation. Cluster 1 includes high-elevation forests, distributed across Italy, monospecific or with low diversity. Cluster 2 includes forests growing in the sub-mountain or in hilly areas, distributed in Northern and Central Italy, with high diversity. Cluster 3 includes sub-mountain forests, distributed especially in Central and North Italy, with low diversity. Cluster 4 includes low-elevation forests distributed in Central and Southern Italy, with low diversity. The most defoliated forests are included in clusters 2 and 4, whereas the less defoliated ones belong to clusters 1 and 3 .

\section{Effects of Neighbouring trees in state and change of crown defoliation}

To examine the influence of tree species of surrounding trees and environmental factors on crown defoliation, the analysis at the neighbourhood level for $P$. abies growing in the Alpine belt in North Italy was carried out. This species was selected because it is one of the most numerous in survey at national level (Table 1). Its distribution is mostly limited in the Alpine belt (see Fig. 1a), so it is possible to consider relatively homogeneous the ecological conditions where it grows and, finally, because it is poorly affected by pests.

The crown defoliation of this species at a given year (2014) and the changes between the years 2006 and 2011 (when the highest increase of defoliation severity was recorded) are shown in relation to the local Shannon Index in Fig. 4a and b, respectively. Crown defoliation levels (Fig. 4a) and change in defoliation intensity (Fig. 4b) showed a slight but significant positive correlation with increasing local tree diversity.

\section{Discussion}

The spatial and temporal pattern of crown defoliation is the result of species-specific behaviours, especially for broad-leaf species that cover a wide range of climatic

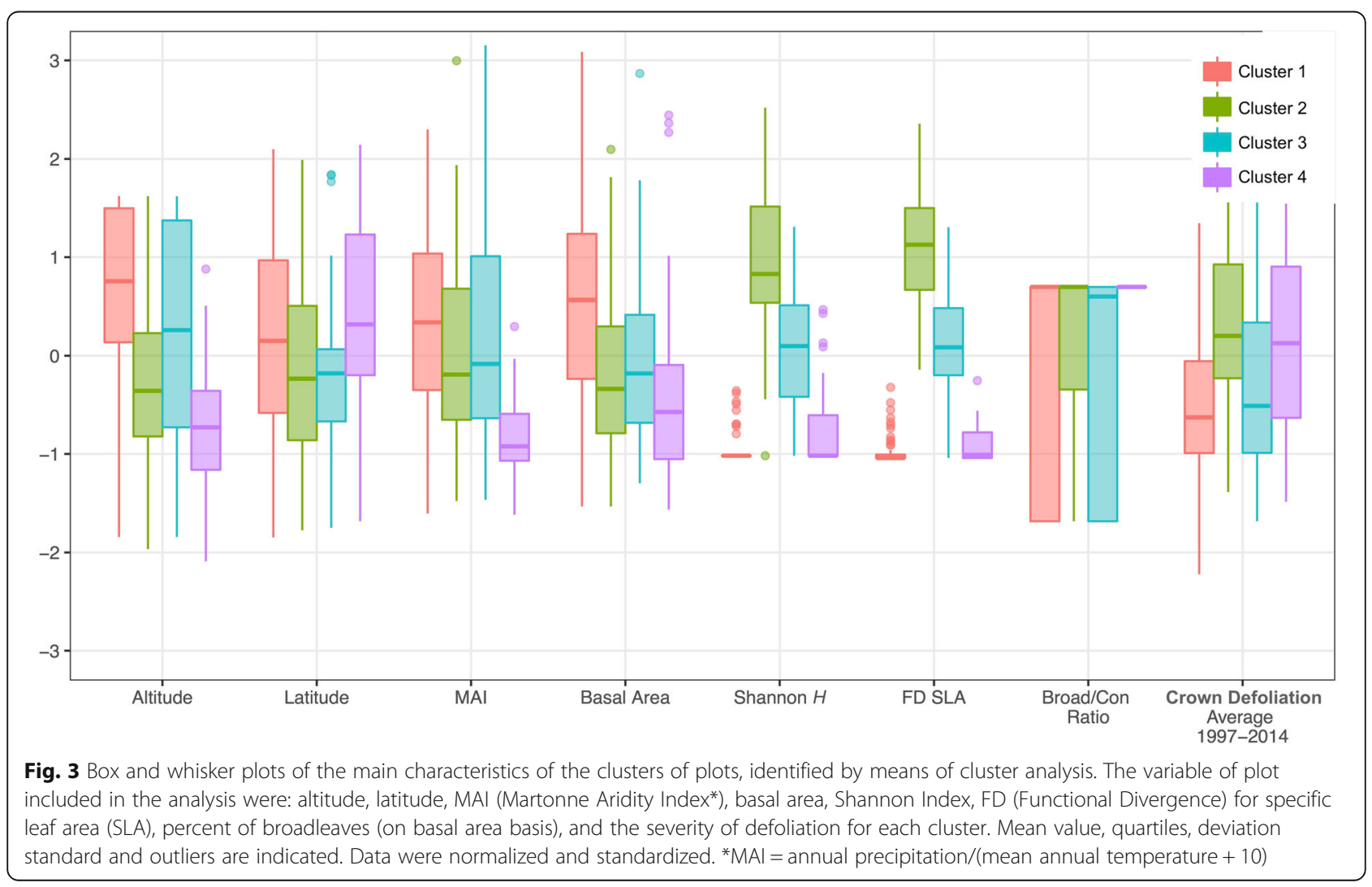



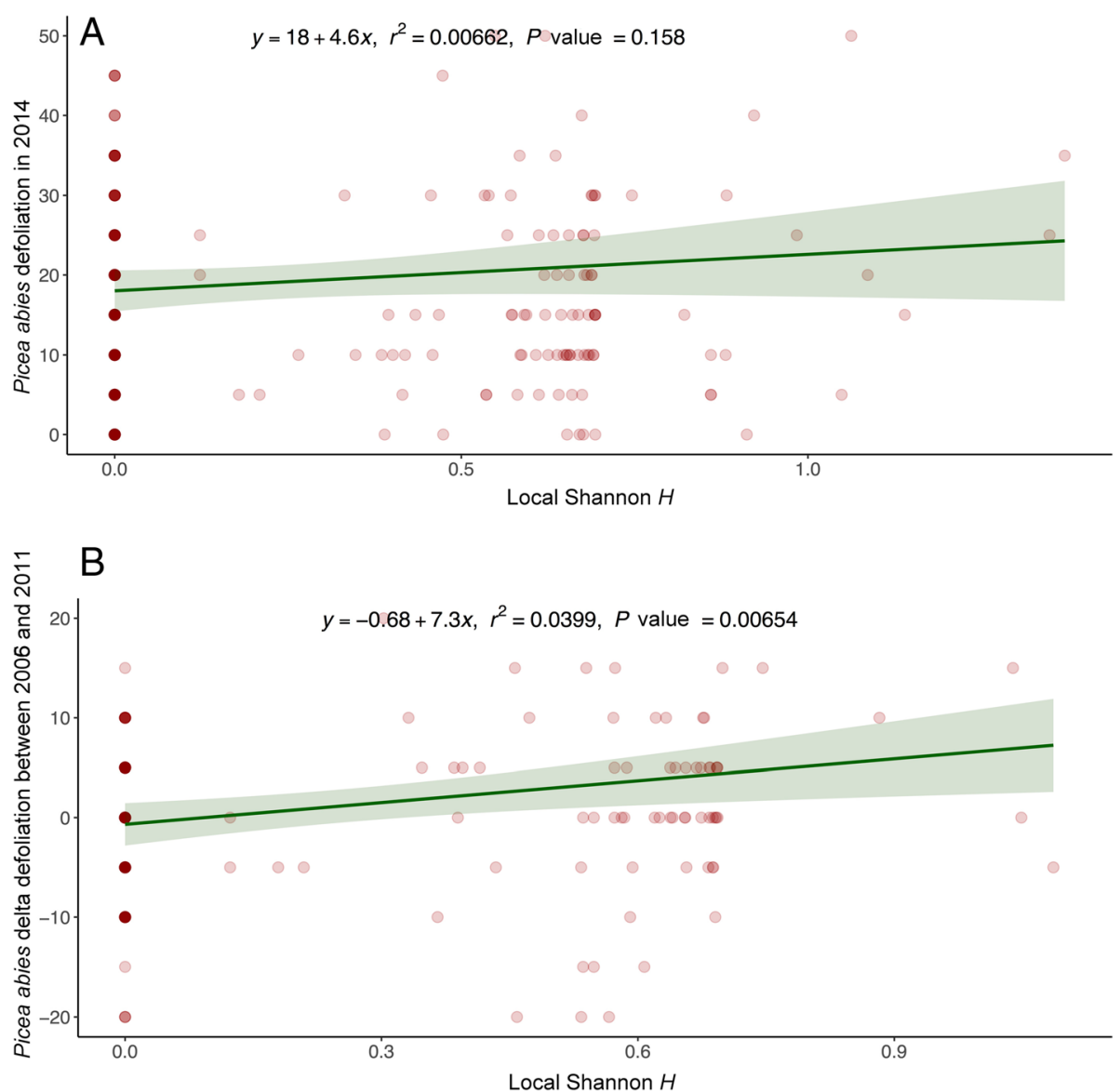

Fig. 4 Defoliation severity levels (year 2014, a) and changes (years 2006-2011, b) in Picea abies trees in relation to the local tree diversity (Shannon Index is calculated in an area with $5 \mathrm{~m}$ radius from the target tree)

and ecological conditions. F. sylvatica, Quercus sp.pl., and Castanea sativa Mill. showed different crown defoliation levels. Based on these considerations, the strong defoliation severity observed in north-western Italy is likely associated with the large presence of $C$. sativa and Pinus sylvestris L., which are the most defoliated species within broadleaves and conifers respectively. For several decades, $C$. sativa has been severely attacked by various pests and diseases (Battisti et al. 2014), whereas $P$. sylvestris populations are declining because of the worsening environmental conditions, with special reference to increasing drought in the southern Alpine belt (Dobbertin et al. 2007), including the regions of North-West Italy (Vacchiano et al. 2012). In these regions elevated levels of ozone pollution were also detected by Sicard et al. (2016).

While broadleaved tree species are widespread over the whole Italian territory and across different climatic regions, conifers are represented mostly by alpine species (P. abies, Larix decidua Mill., P. sylvestris) each of them occupying a specific ecological niche with a distribution limited to Northern Italy (Fig. 1a). The different distribution of the two functional groups (conifers and broadleaves), both spatial and ecological, may imply that they can be subject to different pressures and environmental drivers, thus explaining their different response trend through time. Specific environmental constraints in the Alpine and Mediterranean regions are reviewed by Therillat and Guisan, 2001; Bussotti et al. 2014; Ochoa-Hueso et al. 2017. Finally, the increase over time of the proportion of highly defoliated trees $(>60 \%)$ suggests that defoliation may not be reversible above this threshold.

Since each tree species has its own "signature" in terms of defoliation responses (see also ICP Forests 2016), the spatial distribution of stand-level defoliation is strictly related to the distribution of the most relevant species. European and Italian forests are largely composed by one or few dominant species (Inventario Nazionale Foreste e Serbatoi Forestali Carbonio, http:// www.sian.it/inventarioforestale/; Eurostat http://ec.europa.eu/eurostat/statistics-explained/index.php/Archive:Fo restry_statistics) because of past management and/or environmental constraints. Mixed forests are more likely to 
be found in transition zones, where some of the dominant species grow at their ecological limits and several secondary tree species also occur, as for example in central Italy (Carrari et al. 2016).

Results of the cluster analysis can be interpreted consistently with these considerations. The clusters that display the lower degree of defoliation (groups 1 and 3) include the stands at higher elevations in the Alps (with $P$. abies) and Apennine (with F. sylvatica). These species grow in their optimal climatic conditions and form climax forests, often monospecific or with low diversity (Nocentini 2009; Caudullo and De Rigo, 2016). Picea abies and F. sylvatica are, for conifers and broadleaves respectively, the species with lowest crown defoliation (Table 1). By contrast, in group 2, the forests with high diversity and crown defoliation are located mainly on hills and in the sub-montane belt of both the Alps and the Apennines, where a mixing of mountain conifers at their lower limit and broadleaf species at their upper limit occur at an intermediate altitude occurs. In this area, trees may be subject to variable and non-optimal ecological conditions (Vacchiano et al. 2012). Moreover, the forest vegetation of the subalpine belt includes species severely damaged by pests and fungi, such as $C$. sativa (Battisti et al. 2014). The elevated levels of crown defoliation in group 4 may be associated with the hotter and drier Mediterranean climate. Elevated levels of crown defoliation were in fact found on the Mediterranean region (ICP Forests 2016).

Our preliminary results concerning the role of the surrounding tree species on $P$. abies confirmed the findings previously reported. The positive correlation between crown defoliation and local Shannon Index may be connected to the fact that in its optimal habitat this species tends to form pure stands.

To refine the analyses, introducing variables that describe the structure of the forest is also necessary (Pommerening 2002, 2006; Motz et al. 2010). The interaction between forest structure and tree composition plays a key role in affecting growth and physiological responses of trees under stress (Ruiz-Benito et al. 2013; MadrigalGonzález et al. 2016; Grote et al. 2016). According to Fichtner et al. (2017), the interaction between diversity and structure produces different effects on acquisitive and conservative species, being the first ones favoured by low competition intensity and the latter in more competitive conditions.

\section{Conclusions}

The role of tree diversity as a predictive factor of crown defoliation and overall conditions, may differ in relation to the target species, the kind of mixture and the ecological features at each site, hence to the environmental context (Ratcliffe et al. 2017). In this perspective, it would be helpful to get a larger observational scale by expanding the study from national to the continental (European) level, and in connection to similar ones in North America (Randolph 2013). The ICP Forests programme can play a significant role for the comprehension of all the environmental and structural variables affecting tree health and growth, but some methods and criteria should be reconsidered to make that programme more suitable for the new challenges (Bussotti and Pollastrini 2017a). Among the questions to be addressed, the most relevant is connected probably to the different sampling designs adopted at the national level. According to Motz et al. (2010) the most adequate sampling method to assess tree diversity and related parameters consists in plots with fixed radius, but this design is not adopted everywhere (Ferretti and Fisher 2013). Moreover, the trees should be geo-referenced in the plot to apply the "neighbouring tree" approach, but not always these data are available. Finally, more convincing evidences concerning the actual reliability of tree defoliation as descriptor of overall physiological conditions and growth are necessary.

\section{Acknowledgements}

We are grateful to the former National Forest Service (Corpo Forestale dello Stato, Div. V), now "Carabinieri Forestali", for the collection of field data. Finally, thanks to Giacomo Colle (Effetreseizero srl) and Enrico Cenni (Linnaea-ambiente srl) for the re-organization of archives.

\section{Funding}

This research was funded and carried out within SMART4Action LIFE+ project "Sustainable Monitoring and Reporting to Inform Forest and Environmental Awareness and Protection" LIFE13 ENV/IT/000813.

\section{Availability of data and materials}

The dataset supporting the conclusions of this article is available on request on www.icp-forests.net.

\section{Authors' contributions}

FB and FS are responsible of the general idea and concepts concerning the role of diversity. FB wrote the first version of the text. MF managed the dataset. GI and FM are responsible for the statistical design and analyse. MP participated to the critical analysis of the text and discussion. All authors read and approved the final manuscript.

\section{Competing interests}

The authors declare that they have no competing interests.

\section{Author details}

${ }^{1}$ Department of Agri-Food Production and Environmental Sciences (DISPAA), University of Firenze, Piazzale delle Cascine, 18 -, 50144 Florence, Italy.

${ }^{2}$ Department of Statistical Sciences, University La Sapienza, P.le Aldo Moro 5, 00185 Rome, Italy.

Received: 17 August 2017 Accepted: 15 January 2018

Published online: 06 March 2018

References

Augustatis A, Augustaitiene I, Deltuvas R (2007) Scots pine (Pinus sylvestris L.) crown defoliation in relation to the acidic deposition and meteorology in Lithuania. Water Air Soil Pollu 182:335-348. https://doi.org/10.1007/s11270007-9345-9 
Baeten L, Verheyen K, Wirth C, Bruelheide H, Bussotti F, Finér L, Jaroszewicz B, Selvi F, Valladares F, Allan E, Ampoorter E, Auge H, Avăcăriei D, Barbaro L, Bărnoaiea I, Bastias CC, Bauhus J, Beinhoff C, Benavides R, Benneter A, Berger S, Berthold F, Boberg J, Bonal D, Brüggemann W, Carnol M, Castagneyrol B, Charbonniel Y, Chécko E, Coomes D, Coppi A, Dalmaris E, Dănilă G, Dawud SM, de Vries W, De Wandeler H, Deconchat M, Domisch T, Duduman G, Fischer M, Fotelli M, Gessler A, Gimeno TE, Granier A, Grossiord C, Guyot V, Hantsch L, Hättenschwiler S, Hector A, Hermy M, Holland V, Jactel H, Joly F-X, Jucker T, Kolb S, Koricheva J, Lexer MJ, Liebergesell M, Milligan H, Müller S, Muys B, Nguyen D, Nichiforel L, Pollastrini M, Proulx R, Rabasa S, Radoglou K, Ratcliff S, Raulund-Rasmussen K, Seiferling I, Stenlid J, Vesterdal L, von Wilpert K, Zavala MA, Zielinski D, Scherer-Lorenzen M (2013) A novel comparative research platform designed to determine the functional significance of tree species diversity in European forests. Perspect Plant Ecol 15(5):281-291. https://doi.org/10.1016/j.ppees.2013.07.002

Battisti A, Benvegnù I, Colombari F, Haack RA (2014) Invasion by the chestnut gall wasp in Italy causes significant yield loss in Castanea sativa nut production. Agr Forest Entomol 16:75-79. https://doi.org/10.1111/afe.12036

Bussotti F (2008) Functional leaf traits, plant communities and acclimation processes in relation to oxidative stress in trees: a critical overview. Glob Chang Biol 14(11): 2727-2739. https://doi.org/10.1111/j.1365-2486.2008.01677.x

Bussotti F, Bettini D, Cenni E, Ferretti M, Sarti C, Nibbi R, Capretti P, Stergulc F, Tiberi R (2016) PARTE 2 - Valutazione della condizione delle chiome. In: W AA (ed) Procedure di rilievo nelle aree di saggio e valutazione della condizione delle chiome. Ministero delle Politiche Agricole, Alimentari e Forestali, Roma, Manuale di Campagna

Bussotti F, Cozzi A, Cenni E, Bettini D, Sarti C, Ferretti M (2009) Quality assurance and measurement errors in monitoring tree crown conditions in Italy. J Environ Monitor 11:769-773. https://doi.org/10.1039/b818166g

Bussotti F, Ferrini F, Pollastrini M, Fini A (2014) The challenge of Mediterranean sclerophyllous vegetation under climate change: from acclimation to adaptation. Environ Exp Bot 103:80-98. https://doi.org/10.1016/j.envexpbot 2013.09.013

Bussotti F, Pollastrini M (2017a) Observing climate change impacts on European forests: what works and what does not in ongoing long-term monitoring networks. Front Plant Sci 8:629. https://doi.org/10.3389/fpls.2017.00629

Bussotti F, Pollastrini M (2017b) Traditional and novel indicators of climate change impacts on European forest trees. Forests 8(4):137. https://doi.org/10. 3390/ 8040137

Bussotti F, Pollastrini M, Holland V, Brüggemann W (2015) Functional traits and adaptive capacity of European forests to climate change. Environ Exp Bot 111:91-113. https://doi.org/10.1016/j.envexpbot.2014.11.006

Carnicer J, Coll M, Ninyerola M, Pons X, Sánchez G, Peñuelas J (2011) Widespread crown condition decline, food web disruption, and amplified tree mortality with increased climate change-type drought. P Natl Acad Sci USA (PNAS) 108:1474-1478. https://doi.org/10.1073/pnas.1010070108

Carrari E, Ampoorter E, Coppi A, Selvi F (2016) Diversity of secondary woody species in relation to species richness and cover of dominant trees in thermophilous deciduous forests of central Italy. Scand J Forest Res 31(5): 484-494. https://doi.org/10.1080/02827581.2015.1081981

Castagneyrol B, Giffard B, Péré C, Jactel H (2013) Plant apparency, an overlooked driver of associational resistance to insect herbivoy. J Ecol 101:418-429. https://doi.org/10.1111/1365-2745.12055

Caudullo G, De Rigo D (2016) Picea abies In Europe: distribution, habitat, usage and threats. The European Atlas of Forest Tree Species. http://forest.jrc.ec. europa.eu/european-atlas-of-forest-tree-species/. Accessed 20 Sep 2016

Corona P, Chirici G, McRoberts RE, Winter S, Barbati A (2011) Contribution of largescale forest inventories to biodiversity assessment and monitoring. Forest Ecol Manag 262(11):2061-2069. https://doi.org/10.1016/j,foreco.2011.08.044

de la Cruz AC, Gil PM, Fernandez-Cancio A, Minaya M, Navarro-Cerrillo RM, SanchezSalguero R, Grau JM (2014) Defoliation triggered by climate induced effects in Spanish ICP forests monitoring plots. Forest Ecol Manag 331:245-255. https:// doi.org/10.1016/j.foreco.2014.08.010

De Marco A, Vitale M, Popa I, Anav A, Badea O, Silaghi D, Leca S, Screpanti A, Paoletti E (2017) Ozone exposure affects tree defoliation in a continental climate. Sci Total Environ 596-597:396-404. https://doi.org/10.1016/j. scitotenv.2017.03.135

Dobbertin M, Wermelinger B, Bigler C, Bürgi M, Carron M, Forster B, Gimmi U, Rigling A (2007) Linking increasing drought stress to scots pine mortality and bark beetle infestations. ScientificWorldJournal 7(S1):231-239. https://doi.org/ 10.1100/tsw.2007.58
Drobyshev I, Linderson H, Sonesson K (2007) Relationship between crown condition and tree diameter growth in southern Swedish oaks. Environ Monit Assess 128(1-3):61-73. https://doi.org/10.1007/s10661-006-9415-2

Eichhorn J, Icke R, Isenberg A, Paar U, Schönfelder E (2005) Temporal development of crown condition of beech and oak as a response variable for integrated evaluations. Eur J Forest Res 124:335-347. https://doi.org/10. 1007/s10342-005-0097-z

Eichhorn J, Roskams P, Potocic N, Timermann V, Ferretti M, Mues V, Szepesi A, Durrant D, Seletkovic I, Schröck HW, Nevalainen S, Bussotti F, Garcia P, Wulff S (2016) Part IV: Visual Assessment of Crown Condition and Damaging Agents. In: Manual on methods and criteria for harmonized sampling, assessment, monitoring and analysis of the effects of air pollution on forests, UNECE ICP Forests Programme Coordinating Centre ed;; Thünen Institute of Forest Ecosystems, Eberswalde, p 54. http://icp-forests.net/page/icp-forests-manual. Accessed 20 Sep 2017

Ferretti M (1994) Mediterranean Forest trees. A Guide for Crown Assessment. CEC - UN/ECE, Brussels, Geneva

Ferretti M, Bussotti F, Cenni E, Cozzi A (1999) Implementation of quality assurance procedures in the Italian programs of forest condition monitoring. Water Air Soil Poll 116:371-376

Ferretti M, Fisher R (2013) Development in Environmental Science. In: Forest monitoring: methods for terrestrial investigations in Europe with an overview of North America and Asia, vol vol 12. Elsevier, Amsterdam, p 507

Ferretti M, Nicolas M, Bacaro G, Brunialti G, Calderisi M, Croisé L, Frati L, Lanier M, Maccherini S, Santi E, Ulrich E (2014) Plot-scale modeling to detect size, extent, and correlates of changes in tree defoliation in French high forests. Forest Ecol Manag 311:56-69. https://doi.org/10.1016/j.foreco.2013.05.009

Fichtner A, Härdtle W, Li Y, Bruelheide H, Kunz M, von Oheimb G (2017) From competition to facilitation: how tree species respond to neighbourhood diversity. Ecol Lett 20(7):892-200. https://doi.org/10.1111/ele.12786

Gasparini P, Di Cosmo L, Rizzo M (2016) PARTE 1 - Procedure di rilievo nelle aree di saggio di Livello I. In: W AA (ed) Procedure di rilievo nelle aree di saggio e valutazione della condizione delle chiome. Ministero delle Politiche Agricole, Alimentari e Forestali, Roma, Manuale di Campagna

Green JL, Hastings A, Arzberger P, Ayala FJ, Cottingham KL, Cuddington K, Davis F, Dunne JA, Fortin M-J, Gerber L, Neubert M (2005) Complexity in ecology and conservation: mathematical, statistical, ans computational challenges. Bioscience 55(6):501-510

Grote R, Gessler A, Hommel R, Poschenrieder W, Priesack E (2016) Importance of tree height and social position for drought-related stress on tree growth and mortality. Trees 30(5):1467-1482. https://doi.org/10.1007/s00468-016-1446-x

Guyot V, Castagneyrol B, Vialatte A, Deconchat M, Selvi F, Bussotti F, Jactel H (2015) Tree diversity limits the impact of an invasive Forest Pest. PLoS One 10(9):e0136469. https://doi.org/10.1371/journal.pone.0136469

Huber DPW, Borden JH (2001) Angiosperm bark volatiles disrupt response of douglas-fir beetle, Dendroctonus pseudotugae, to attractant-baited traps. J Chem Ecol 27(2):217-233

ICP Forests (2016) 30 Years of Monitoring the Effects of Long Range Transboudary Air Pollution on Forests in Europe and beyond. http://icpforests.net/page/icp-forests-technical-report. Accessed 10 March 2017

Jactel H, Brockerhoff EG (2007) Tree diversity reduces herbivory by forest insects. Ecol Lett 10(9):835-848. https://doi.org/10.1111/j.1461-0248.2007.01073.x

Johnson J, Jacob M (2009) Monitoring the effects of air pollution on forest condition in Europe: is crown defoliation an adequate indicator? iForest 3: 86-88. https://doi.org/10.3832/ifor0538-003

Jucker T, Bouriaud O, Avacaritei D, Coomes D (2014) Stabilizing effects of diversity on aboveground wood production in forest ecosystems: linking patterns and processes. Ecol Lett 17(12):1560-1569. https://doi.org/10.1111/ele.12382

Jules ES, Carroll AL, Garcia AM, Steenbock CM, Kauffman MJ (2014) Host heterogeneity influences the impact of a non-native disease invasion on populations of a foundation tree species. Ecosphere 5(9):1-17. https://doi. org/10.1890/ES14-00043.1

Klap JM, Oude Voshaar JH, De Vries W, Erisman JW (2000) Effects of environmental stress on forest crown condition in Europe. Part IV: statistical analyses of relationships. Water Air Soil Poll 119:387-420

Lavorel S, Grigulis K, Mcintyre S, Williams NSG, Garden D, Dorrough J, Berman S, Quétier F, Thébault A, Bonis A (2008) Assessing functional diversity in the field - methodology matters! Funct Ecol 22(1):134-147. https://doi.org/10. 1111/j.1365-2435.2007.01339.x

Leuzinger S, Luo Y, Beier C, Dielemann W, Vicca S, Körner C (2011) Do global change experiments overestimate impacts on terrestrial ecosystems? Trends Ecol Evol 26(5):236-241. doi:https://doi.org/10.1016/j.tree.2011.02.011 
Liang J, Crowther TW, Picard N, Wiser S, Zhou M, Alberti G, Schulze ED, McGuire AD, Bozzato F, Pretzsch H, de Miguel S, Paquette A, Herault B, Scherer-Lorenzen M, Barrett CB, Glick HB, Hengeveld GM, Nabuurs GJ, Pfautsch S, Viana H, Vibrans AC, Ammer C, Schall P, Verbyla D, Tchebakova N, Fischer M, Watson JV, HYH C, Lei XD, Schelhaas MJ, Lu HC, Gianelle D, Parfenova El, Salas C, Lee E, Lee B, Kim HS, Bruelheide H, Coomes DA, Piotto D, Sunderland T, Schmid B, Gourlet-Fleury S, Sonke B, Tavani R, Zhu J, Brandl S, Vayreda J, Kitahara F, Searle EB, Neldner VJ, Ngugi MR, Baraloto C, Frizzera L, Balazy R, Oleksyn J, Zawila-Niedzwiecki T, Bouriaud O, Bussotti F, Finer L, Jaroszewicz B, Jucker T, Valladares F, Jagodzinski AM, Peri PL, Gonmadje C, Marthy W, O'Brien T, Martin EH, Marshall AR, Rovero F, Bitariho R, Niklaus PA, Alvarez-Loayza P, Chamuya N, Valencia R, Mortier F, Wortel V, Engone-Obiang NL, Ferreira LV, Odeke DE, Vasquez RM, Lewis SL, Reich PB (2016) Positive biodiversity-productivity relationship predominant in global forests. Science 354. https://doi.org/10.1126/science.aaf8957

Liebergesell M, Reu B, Stahl U, Freiberg M, Welk E, Kattge J, JHC C, Peñuelas J, Wirth C (2016) Functional resilience against climate-driven extinctions - comparing the functional diversity of European and north American tree floras. PLoS One 11(2):e0148607. https://doi.org/10.1371/journal.pone.0148607

Lindén M, Vollbrecht G (2002) Sensitivity of Picea abies to butt rot in pure stands and in mixed stands with Pinus sylvestris in southern Sweden. Silva Fenn 36(4):767-778

Lodge DJ, Cantrell S (1995) Fungal communities in wet tropical forests: variation in time and space. Can J Bot 73(S1):1391-1398

Lorenz M, Fischer R, Becher G, Granke O, Roskams P, Nagel HD, Kraft Ph (2007) Forest condition in Europe 2007-technical report of ICP forests. Federal Research Centre for forestry and Forest products (BFH) and Department of Wood Science, University of Hamburg

Madrigal-González J, Ruiz-Benito P, Ratcliffe S, Calatayud J, Kändler G, Lehtonen A, Dahlgren J, Wirth C, Zavala MA (2016) Complementarity effects on tree growth are contingent on tree size and climatic conditions across Europe. Sci Rep 6:32233. https://doi.org/10.1038/srep32233

Maechler M, Rousseeuw P, Struyf A, Hubert M, Hornik K (2016). Cluster: cluster analysis basics and extensions. R package version 2.0.5

Maloney PE, Lynch SC, Kane S, Jensen CE, Rizzo DM (2005) Establishment of an emerging generalist pathogen in redwood forest communities. J Ecol 93(5): 899-905. https://doi.org/10.1111/j.1365-2745.2005.01031.x

Michel A, Seidling W (2016) Forest condition in Europe: 2016 technical report of ICP forests. Report under the UNECE convention on long-range transboundary air pollution (CLRTAP). BFWDokumentation 23/2016. BFW Austrian Research Centre for Forests, Vienna, p 206

Motz K, Sterba H, Pommerening A (2010) Sampling measures of tree diversity. Forest Ecol Manag 260(11):1985-1996. https://doi.org/10.1016/j.foreco.2010.08.046

Müller E, Stierlin HR (1990) Tree crown photos. Sanasilva. Swiss Federal Institute for Forest Snow and Landscape Research, Birmensdorf

Nakajima H, Kume A, Ishida M, Ohmiya T, Mizoue N (2011) Evaluation of estimates of crown condition in forest monitoring: comparison between visual estimation and automated crown image analysis. Ann For Sci 68(8): 1333-1340. https://doi.org/10.1007/s13595-011-0132-9

Nguyen D, Castagneyrol B, Bruelheide H, Bussotti F, Guyot V, Jactel H, Jaroszewicz B, Valladares F, Stenlid J, Boberg J (2016) Fungal disease incidence increases with tree diversity and latitude in European forest. Ecol Evol 6(8):2426-2438. https://doi.org/10.1002/ece3.2056

Nocentini S (2009) Structure and management of beech (Fagus sylvatica L.) forests in Italy. iForest 2:105-113. https://doi.org/10.3832/ifor0499-002

Ochoa-Hueso R, Munzi S, Alonso R, Crespo MA, Avila A, Bermejo V, Bobbink R, Braquinho C, Concostrina-Zubiri L, Cruz C, de Carvalho RC, De Marco A, Dias T, Elustondo D, Elvira S, Estébanez B, Fusaro L, Gerosa G, Izquieta-Rojano S, Lo Cascio M, Marzuoli R, Matos P, Mereu S, Merino J, Morillas L, Nunes A, Paoletti E, Paoli L, Pinho P, Rogers IB, Santos A, Sicard P, Stevens CJ, Theobald MR (2017) Ecological impacts of atmospheric pollution and interaction with climate change in terrestrial ecosystems of the Mediterranean Basin: current research and future directions. Environ Pollut 227:194-206. https://doi.org/10.1016/j.encpol.2017.04.062

Parker IM, Saunder M, Bontrager M, Weitz AP, Hendricks R, Magarey R, Suiter K, Gilbert GS (2015) Phylogenetic structure and host abundance drive disease pressure in communities. Nature 520:542-544. https://doi.org/10.1038/nature14372

Pollastrini M, Feducci M, Bonal D, Fotelli M, Gessler A, Gossiord C, Guyot V, Jactel H, Nguyen D, Radoglou K, Bussotti F (2016) Physiological significance of forest tree defoliation: results from a survey in a mixed forest in Tuscany (central Italy). Forest Ecol Manag 361:170-178. https://doi.org/10.1016/j.foreco.2015.11.018

Pollastrini M, Holland V, Brüggemann W, Bruelheide H, Dănilă IC, Jaroszewicz B, Valladares F, Bussotti F (2016) Taxonomic and ecological relevance of the chlorophyll a fluorescence signature of tree species in mixed European forests. New Phytol 212(1):51-65. https://doi.org/10.1111/nph.14026

Pollastrini M, Maggino F, Bonal D, Brueggemann W, Fotelli M, Gessler A, Grossiord C, Holland V, Guyot V, Jactel H, Nguyen D, Radoglou K, Stenlid J, Bussotti F (2015) Towards a new multidimensional indicator of tree crown status. In: Tiia L, Urmas P, Ajith P (eds) Sustaining ecosystem services in forest landscapes. Proceeding of IUFRO landscape ecology conference sustaining ecosystem services in forest landscapes - concepts, research, and applications, Tartu, 23-30 august 2015, p 126

Pommerening A (2002) Approaches to quantifying forest structures. Forestry 75(3):305-324

Pommerening A (2006) Evaluating structural indices by reversing forest structural analysis. Foreat Ecol Manag 224(3):266-277. https://doi.org/10.1016/j.foreco. 2005.12.039

Popa I, Badea O, Silaghi D (2017) Influence of climate on tree health evaluated by defoliation in the ICP level I network (Romania). iForest 10:554-560. https://doi.org/10.3832/ifor2202-009

R Core Team (2016) R: a language and environment for statistical computing. $R$ Foundation for Statistical Computing, Vienna https://www.R-project.org/. Accessed 20 Sep 2016

Randolph KDC (2013) Development history and bibliography of the US Forest Service crown-condition indicator for forest health monitoring. Environ Monit Assess 185(6):4977-4993. https://doi.org/10.1007/s10661-012-2919-z

Rao CR (1982a) Diversity and dissimilarity coefficients: a unified approach. Theor Popul Biol 21(1):24-43

Rao CR (1982b) Diversity: its measurement, decomposition, apportionment and analysis. Sankhya Ser A 44(1):1-22

Ratcliffe S, Liebergesell M, Ruiz-Benito P, González JM, Muñoz Castañeda JM, Kändler G, Lehtonen A, Dahlgren J, Kattge J, Peñuelas J, Zavala MA, Wirth C (2015) Modes of functional biodiversity control on tree productivity across the European continent. Glob Ecol Biogeogr 25(3):251-262. https://doi.org/10.1111/geb.12406

Ratcliffe S, Wirth C, Jucker T, van der Plas F, Scherer-Lorenzen M, Verheyen K, Allan E, Benavides R, Bruelheide H, Ohse B, Paquette A, Ampoorter E, Crespo Bastias C, Bauhus J, Bonal D, Bouriaud O, Bussotti F, Carnol M, Castagneyrol B, Chećko E, Muhie Dawud S, De Wandeler H, Domisch T, Finér L, Fischer M, Fotelli M, Gessler A, Granier A, Grossiord C, Guyot V, Haase J, Hättenschwiler S, Jactel H, Jaroszewicz B, Joly F-X, Kambach S, Kolb S, Koricheva J, Liebersgesell M, Milligan H, Müller S, Muys B, Nguyen D, Nock C, Pollastrini M, Purschke O, Radoglou K, Raulund-Rasmussen K, Roger F, Ruiz-Benito P, Seidl R, Selvi F, Seiferling I, Stenlid J, Valladares F, Vesterdal L, Baeten L (2017) Biodiversity and ecosystem functioning relations in European forests depend on environmental context. Ecol Lett 20(11):1414-1426. https://doi.org/10.1111/ele.12849

Root RB (1973) Organization of a plant-arthropod association in simple and diverse habitats: the fauna of collards (Brassica oleracea). Ecol Monogr 43(1):95-124

Ruiz-Benito P, Gómez-Aparicio L, Paquette A, Messier C, Kattge J, Zavala MA (2014) Diversity increases carbon storage and tree productivity in Spanish forests. Glob Ecol Biogeogr 23(3):311-322. https://doi.org/10.1111/geb.12126

Ruiz-Benito P, Lines ER, Gómez-Aparicio L, Zavala MA, Coomes DA (2013) Patterns and drivers of tree mortality in Iberian forests: climatic effects are modified by competition. PLoS One 8(2):e56843. https://doi.org/10.1371/journal.pone.0056843

Russell EP (1989) Enemies hypothesis: a review of the effect of vegetational diversity on predatory insects and parasitoids. Environ Entomol 18(4):590-599

Sicard P, De Marco A, Dalstein-Richter L, Tagliaferro F, Renou C, Paoletti E (2016) An epidemiological assessment of stomatal ozone flux-based critical levels for ozone injury in southern European forests. Sci Total Environ 541:729-741. https://doi.org/10.1016/j.scitotenv.2015.09.113

Therillat J-P, Guisan A (2001) Potential impact of climate change on vegetation in the European alps: a review. Clim Chang 50:77-109

Thor M, Ståhl G, Stenlid J (2005) Modelling root rot incidence in Sweden using tree, site and stand variables. Scand J Forest Res 20(2):165-176. https://doi. org/10.1080/02827580510008347

Vacchiano G, Garbarino M, Mondino EB, Motta R (2012) Evidences of drought stress as a predisposing factor to scots pine decline in Valle d'Aosta (Italy). Eur J For Res 131(4):989-1000. https://doi.org/10.1007/s10342-011-0570-9

Verheyen K, Vanhellemont M, Auge H, Baeten L, Baraloto C, Barsoum N, BilodeauGauthier S, Bruelheide H, Castagneyrol B, Godbold D, Haase J, Hector A, Jactel H, Koricheva J, Loreau M, Mereu S, Messier C, Muys B, Nolet P, Paquette A, Parker J, Perring M, Ponette Q, Potvin C, Reich P, Smith A, Weih M, Scherer-Lorenzen M (2016) Contributions of a global network of tree diversity experiments to sustainable forest plantations. Ambio 45(1):29-41. https://doi.org/10.1007/s13280-015-0685-1 
Watson JV, Liang J, Tobin PC, Lei X, Rentch JS, Artis CE (2015) Large-scale forest inventories of the United States and China reveal positive effects of biodiversity on productivity. For Ecosyst 2:22. https://doi.org/10.1186/s40663014-0045-4

Wickham H (2009) ggplot2: elegant graphics for data analysis. Springer-Verlag, New York

\section{Submit your manuscript to a SpringerOpen ${ }^{\circ}$} journal and benefit from:

- Convenient online submission

- Rigorous peer review

- Open access: articles freely available online

- High visibility within the field

- Retaining the copyright to your article

Submit your next manuscript at $\boldsymbol{\sim}$ springeropen.com 